\title{
Detection of Toxoplasma gondii copro-prevalence by polymerase chain reaction using repetitive 529 bp gene in feces of pet cats (Felis catus) in Yogyakarta, Indonesia
}

\author{
Muhammad Hanafiah ${ }^{1}$, Joko Prastowo², Sri Hartati ${ }^{3}$ Dwinna Aliza ${ }^{4}$ and Raden Wisnu Nurcahyo
}

1. Parasitology Laboratory, Faculty of Veterinary Medicine, Syiah Kuala University, Banda Aceh, Indonesia; 2. Department of Parasitology, Faculty of Veterinary Medicine, Gadjah Mada University, Yogyakarta, Indonesia; 3. Department of Clinic, Faculty of Veterinary Medicine, Gadjah Mada University, Yogyakarta, Indonesia; 4. Pathology Laboratory, Faculty of Veterinary Medicine, Syiah Kuala University, Banda Aceh, Indonesia.

Corresponding author: Raden Wisnu Nurcahyo, email: wisnu-nc@ugm.ac.id

Co-authors: MH: hanafi_2015@unsyiah.ac.id, JP: joko2465@yahoo.com,SH: Toxocat2001@yahoo.com, DA: dwinna2000@yahoo.com

Received: 26-04-2018, Accepted: 31-07-2018, Published online: 28-09-2018

doi: 10.14202/vetworld.2018.1338-1343 How to cite this article: Hanafiah M, Prastowo J, Hartati S, Aliza D, Nurcahyo RW (2018) Detection of Toxoplasma gondii copro-prevalence by polymerase chain reaction using repetitive 529 bp gene in feces of pet cats (Felis catus) in Yogyakarta, Indonesia, Veterinary World, 11(9): 1338-1343.

\begin{abstract}
Aim: The aim of this research was to determine the copro-prevalence of Toxoplasma gondii using polymerase chain reaction (PCR) with repetitive $529 \mathrm{bp}$ gene and to construct the phylogenetic tree of Toxoplasma oocyst from pet cats in Yogyakarta.

Materials and Methods: 9 of 132 pet cat samples which serologically positive for Toxoplasma were used in this research. To determine the copro-prevalence of $T$. gondii in pet cat, $10 \mathrm{~g}$ of feces samples taken from practitioners and household cats in Yogyakarta were used in the PCR method utilizing repetitive 529 bp gene sequences.

Results: The result shows that copro-prevalence by PCR using repetitive 529 bp gene was 33.3\% (3/9). The phylogenetic tree of Toxoplasma grouped into two clades, which clade 1 consists of Toxoplasma isolates collected from pet cats in Yogyakarta Indonesia and $T$. gondii isolates from China and in clade 2 consist of the $T$. gondii isolates from India.
\end{abstract}

Conclusion: Copro-prevalence of T. gondii in pet cats in Yogyakarta by means of PCR using repetitive 529 bp gene is around $33.3 \%$.

Keywords: copro-prevalence, pet cat, polymerase chain reaction, Toxoplasma gondii.

\section{Introduction}

Toxoplasma gondii infections are prevalent in humans and animals worldwide. It has been estimated that one-third of the world population has been exposed to this parasite [1]. Toxoplasmosis showed no specific symptoms on domestic cats but may cause chronic illness and clinical symptoms in neonates, geriatric, and immunocompromised animals [2]. Felines are the final or definitive hosts of $T$. gondii while human and all other warm-blooded animals are as intermediate hosts [3]. In humans, the most common routes of $T$. gondii transmission are through ingestion of undercooked meat which contains cysts, poorly washed vegetables, and water or soil contaminated with oocysts [4]. Determination of toxoplasmosis diagnosis is inaccurate by clinical approach since infection is asymptomatic or subclinical in chronic infection, especially on immunocompetent hosts. Some clinical symptom data have been collected

Copyright: Hanafiah, et al. Open Access. This article is distributed under the terms of the Creative Commons Attribution 4.0 International License (http://creativecommons.org/licenses/ by/4.0/), which permits unrestricted use, distribution, and reproduction in any medium, provided you give appropriate credit to the original author(s) and the source, provide a link to the Creative Commons license, and indicate if changes were made. The Creative Commons Public Domain Dedication waiver (http:// creativecommons.org/publicdomain/zero/1.0/) applies to the data made available in this article, unless otherwise stated. from the examination of body temperature, breath, and pulse frequencies [5]. The results showed that all samples still in the normal standard of healthy cat. However, the clinical data were not specific enough to diagnose cat with toxoplasmosis [6]. Various serological and molecular tests have been widely used by researchers in epidemiological studies on animal and human toxoplasmosis worldwide [7].

Molecular diagnostic method for toxoplasmosis such as polymerase chain reaction (PCR) which is simple and sensitive has been produced and able to be implemented on all clinical samples [8-10]. Diagnosis of toxoplasmosis has been improved by the emergence of molecular technologies to amplify parasite nucleic acids. Among these, PCR-based molecular techniques have been used for the genetic characterization of $T$. gondii [11]. PCR requires only common molecular biology experience since it easily differentiates $T$. gondii from other cyst forming eukaryotes and is highly sensitive $[12,13]$.

Molecular diagnostics of toxoplasmosis were generally based on detection of specific DNA sequences. Some use B1 gene that has 35 copies in the genome, but others use DNA R529 bp fragment that has 200-300 copies in genome, internal transcribed spacer - 1 that consists 110 gen copies, or $18 \mathrm{~s}$ rRNA gene sequence [4]. Qualitative PCR to detect single gen copy such as P30 was not sensitive and 
less commonly used for the diagnostic purpose [14]. Garcia et al. [15] have used repetitive 529 bp sequence and Tox 4 and Tox 5 primers to detect $T$. gondii within pig tissue and compared it with mouse bioassay and histopathology. The advance of molecular-based copro-diagnostic method is hoped to be used in detecting T. gondii [16-18].

The objective of this research was to determine the copro-prevalence of $T$. gondii using PCR with repetitive 529 bp gene and to construct Toxoplasma oocyst phylogenetic tree from pet cats in Yogyakarta.

\section{Materials and Methods}

\section{Ethical approval}

This study was approved by the Ethics Committee of Ethical Clearance for Pre-Clinical Research, Integrated Research and Testing Laboratory, Gadjah Mada University, Yogyakarta, Indonesia (Approval no. 00111/09).

\section{Sample preparation}

Samples used in this research were 132 cats obtained from some areas which randomly selected in Yogyakarta, namely Yogyakarta city, Sleman, Bantul, Kulon Progo, and Gunung Kidul. $10 \mathrm{~g}$ of feces of each cat was collected and put into plastic bag and labeled before brought to the Laboratory of Parasitology Faculty of Veterinary Medicine Gajah Mada University. All samples were stored in $4^{\circ} \mathrm{C}$ refrigerator.

\section{Centrifuge method}

$2 \mathrm{~g}$ of feces samples were placed in a mortar, added with distilled water, stirred until mixed, and then poured into centrifuge tube up to $3 / 4$ of the tube's height. The tube was then spun at $2000 \mathrm{rpm}$ for $5 \mathrm{~min}$. The clear supernatant was discarded, and saturated $\mathrm{NaCl}$ solution was added until $3 / 4$ of tube's height after which the tube was spun again in $2000 \mathrm{rpm}$ for $5 \mathrm{~min}$. The centrifuge tube was placed straight up in a rack and then saturated $\mathrm{NaCl}$ was dripped until the water surface reached the top and seemed concave before stored for $3 \mathrm{~min}$. Object glass was touched on the water surface carefully and reversed. The surface of the object glass which touched the water surface was covered by cover glass and examined under the microscope [19].

\section{Toxoplasma oocyst DNA isolation}

Feces samples obtained from feces examination by floatation method were carefully transferred to a new tube, where distilled water was added up to 1.5 of the tube's height. Samples were then centrifuged in $2000 \mathrm{~g}$ for $15 \mathrm{~min}$. The oocyst was then extracted by 200 ul of ASL from the QIAamp DNA Stool Mini Kit (QIAGEN). Extraction was done by adding proteinase in $60^{\circ} \mathrm{C}$ temperature for $1 \mathrm{~h}$. The solution was then eluted within QIAAmp column up until $200 \mu 1$. DNA samples were then placed according to QIAAmp kit direction in $-20^{\circ} \mathrm{C}$ until used.

\section{T. gondii specific PCR}

PCR was carried out with a total volume of $50 \mathrm{ml}$ solution consisting of $10 \mathrm{ml}$ of sample DNA.
Primer TOX4 (50-CGCTGCAGGG AGGAAGACG AAAGTTG-30) and TOX5 (50-CGCTGCAGAC ACAGTGCATCTGGATT-30) used 5' and 3' end in $529 \mathrm{bp}$ repetitive sequence [20]. PCR mixture containing $0.2 \mathrm{mM}$ of each primers, $100 \mathrm{mM}$ dNTP (Fermentas), $60 \mathrm{mM}$ Tris- $\mathrm{HCl}(\mathrm{pH} 9.0), 15 \mathrm{mM}\left(\mathrm{NH}_{4}\right)$ 2SO4, $2 \mathrm{mM} \mathrm{MgCl}$, and $1 \mathrm{U}$ Biotaq (Bioline, MA, USA) per reaction. Amplification was done by PTC150 MiniCycler thermocycler (MJ Research Inc, MA, USA) with the first denaturation for $7 \mathrm{~min}$ in $94^{\circ} \mathrm{C}$, followed by 35 cycles of $1 \mathrm{~min}$ in $95^{\circ} \mathrm{C}, 1 \mathrm{~min}$ in $60^{\circ} \mathrm{C}, 1 \mathrm{~min}$ in $72^{\circ} \mathrm{C}$, and final incubation of $10 \mathrm{~min}$ in $72^{\circ} \mathrm{C}$. Subsequently, the positive control that was DNA comparative to five T. gondii tachyzoites and negative control without DNA product were run in $1.1 \%$ agarose gel electrophoresis added with ethidium bromide, using $1 \mathrm{~Kb}$ DNA ladder as a marker (Biolabs, MA, USA).

\section{Sequencing}

PCR product obtained was sequenced by ABI Prism BigDye Terminator Cycle Sequencing Kit (Applied Biosystems, Foster City, CA, USA). Sequence product was analyzed by program BioEdit and MEGA 6 software (USA).

\section{Statistical analysis}

$T$. gondii copro-prevalence data in pet cats were analyzed descriptively. The Toxoplasma oocyst was then constructed for the phylogenetic tree using the neighbor-joining method.

\section{Results}

\section{Centrifuge method}

The examination using the centrifugation method showed that 9 out of 132 pet cats were positive toxoplasmosis proven by the presence of Toxoplasma oocyst in pet cat feces samples in Yogyakarta appeared as shown in Figure-1.

The centrifuged method revealed that the Toxoplasma oocyst was found in pet cat feces, proven by the size of the oocyst with the diameter ranging from $9.37 \mu \mathrm{m} \times 11.25 \mu \mathrm{m}$. The finding of the

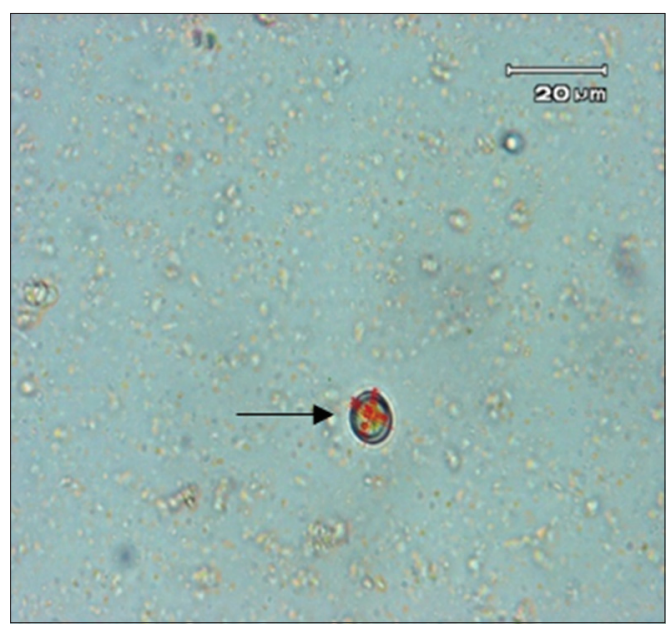

Figure-1: Micrograph of Toxoplasma gondii oocyst sheds by naturally infected pet cat (scale bar $=20 \mu \mathrm{m}$ ) (arrow). 
measurement indicates that the oocyst was positive belongs to toxoplasma genus not from other protozoa such as Hammondia spp. or Sarcocystis spp.

\section{Molecular identification and sequencing analysis}

Partial amplification of repetitive 529 bp gene showed that 3 of 9 samples $(33.3 \%)$ were positive as shown in Figure-2. BLASTN (Basic Alignment Search Tool) analysis was conducted online using http//www.ncbi.nlm.nih.gov. The analysis results are shown in Figure-3.

Figure-3 shows the alignment result, which revealed that the homology level of $T$. gondii repetitive sequencing products compare to other strain is varies ranging from $83 \%$ to $91 \%$. The identical level of $91 \%$ are revealed from sequence in Genbank accession number of KC607824.1, DQ779189.1, FJ656209.1 and HM569600.1, while the identical level of $90 \%$ was with EF195646.1, DQ779193.1, DQ779192.1, LN714508.1, DQ779191.1,LN714493.1, DQ779190.1, DQ779194.1,AF146527.1, DQ779188.1,DQ779195.1, KF872166.1, and EF648168.1, identical level of 89\% with DQ779187.1, EF648169.1, and AF487550.1, identical level of $88 \%$ with HM569598.1, share identical level of $87 \%$ with HM569599.1, identical level of $84 \%$ with HM569602.1, identical level of $83 \%$ with HM569597.1 and HM569603.1.

The genetic relatedness of the identified strain was determined through phylogenetic analysis (Figure-4).

\section{Discussion}

\section{Centrifuge method}

The examination using the centrifugation method shows that 11 of 132 cats were positive toxoplasmosis proven by the presence of Toxoplasma oocyst (Figure-1). Oocyst of T. gondii is structurally similar to those of H. hammondia and Sarcocystis sp. that is also using cats as definitive host. Simamora et al. [21] suggested some further procedures to identify $T$. gondii oocysts in feline feces which were used in this study: (i) Measurement of oocyst diameter, (ii) detection of

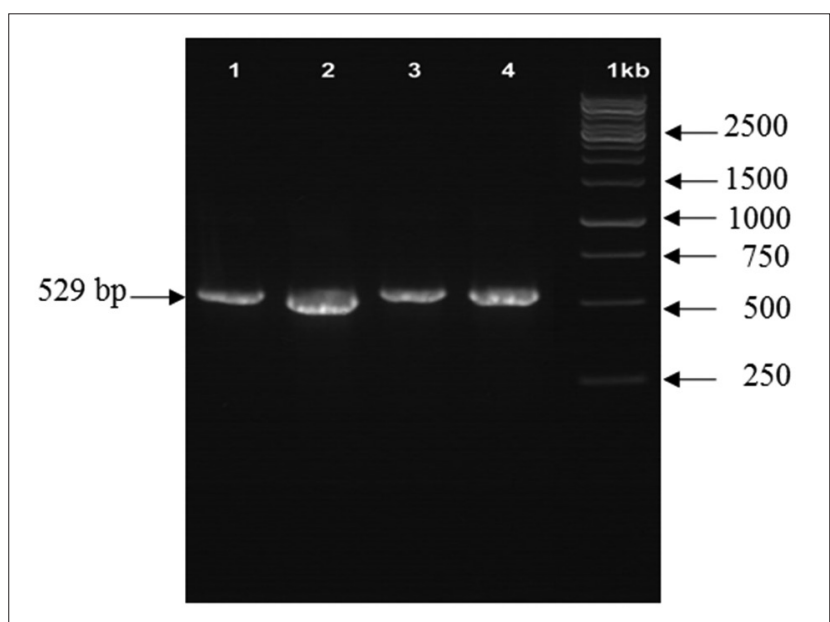

Figure-2: Amplification result of repetitive 529 gene Toxoplasma oocyst on $1 \%$ agarose gel. Annotation: M: 1 kb DNA ladder, 1-3: Samples, 4: Control (tachyzoite).
T. gondii specific 529 bp amplicon, (iii) recovery of $T$. gondii cysts from mice and cat tissue, and (iv) infectivity of cysts to mice. Based on the measurement, it showed that the size of the oocyst found was ranging from $9.37 \mu \mathrm{m} \times 11.25 \mu \mathrm{m}$, which in range of the Toxoplasma oocyst $(<12 \mu \mathrm{m})$ [21].

The copro-prevalence level of Toxoplasma in cat in this study was $8.33 \%$ which higher than the study reported by Liang et al. [22] which was $4 \%$ in Kunming, China. However, this result was lower than those reported by Dubey et al. [23] which was $19 \%$ in Ethiopia and in wildcat $(90 \%)$ and pet cat $(36 \%)$ in Tehran [24]. In addition, the level infection of T. gondii in cat in Kerman was $32.1 \%$ [25]. These various results showed not only depend on the exposure of oocyst but also the sensitivity of the method used by researcher.

\section{Molecular identification and sequencing analysis}

The observation of pet cat oocyst in Yogyakarta using PCR confirmation based on repetitive 529 bp gene (Figure-2) obtained the copro-prevalence level was $33.3 \%$. This is higher than those reported by Dubey [26] that was 9.0\%. Virgen et al. [27] and Bolais et al. [28] stated that in a study using PCR confirmation in wildcat found that the prevalence was $5.9 \%$ and $3.74 \%$ whereas [29] using nested PCR in South Korea found higher prevalence $(47.2 \%)$ in cat.

The overall prevalence of seroreagent cats from the Brazilian semi-arid for $T$. gondii was $43.8 \%$. We found a prevalence of $47.7 \%$ in domiciled cats and $36.2 \%$ in stray cats [30]. The incidence of oocyst shedding in the cat population studied was significantly higher than expected and higher than found in most cat population worldwide [31]. Three samples, (from 1 stray and 2 indoor/outdoor pets), yielded sequences with high identity to $T$. gondii isolates, and were identified as positive for $T$. gondii oocytes.

The study conducted by Bizhga [31] demonstrated that the prevalence of $T$. gondii infection among pet cats was low due to the cats being strictly kept indoors, restricted from eating raw food and uncooked meat and having no chance to contact with other wild animals and the ground after adoption. The positive result of $T$. gondii in pet cats was obtained using ELISA while in stray cats from the animal shelter and clinics revealed the positive result of $T$. gondii by using PCR. Furthermore, the examination of 442 pet cats which always contact with human resulted in $1.8 \%$ was positive toxoplasmosis using coproscopic examination within 10 years period (2006-2016) in Tirana area. Another factor effect the positive result of toxoplasmosis was age, proven by the research result by Gashout et al. [32] that showed at the age of young cats (up to 1-year-old) was $3.22 \%(6 / 168)$, in adults (1-8 years old) was $1.3 \%(2 / 153)$, and at old cats ( $>9$ years old) was $0 \%(0 / 121)$. Furthermore, Nascimentoa et al.[33] reported that the PCR assay showed highly sensitive detection results when using $<10$ tachyzoites of T. gondii DNA and a minimum 


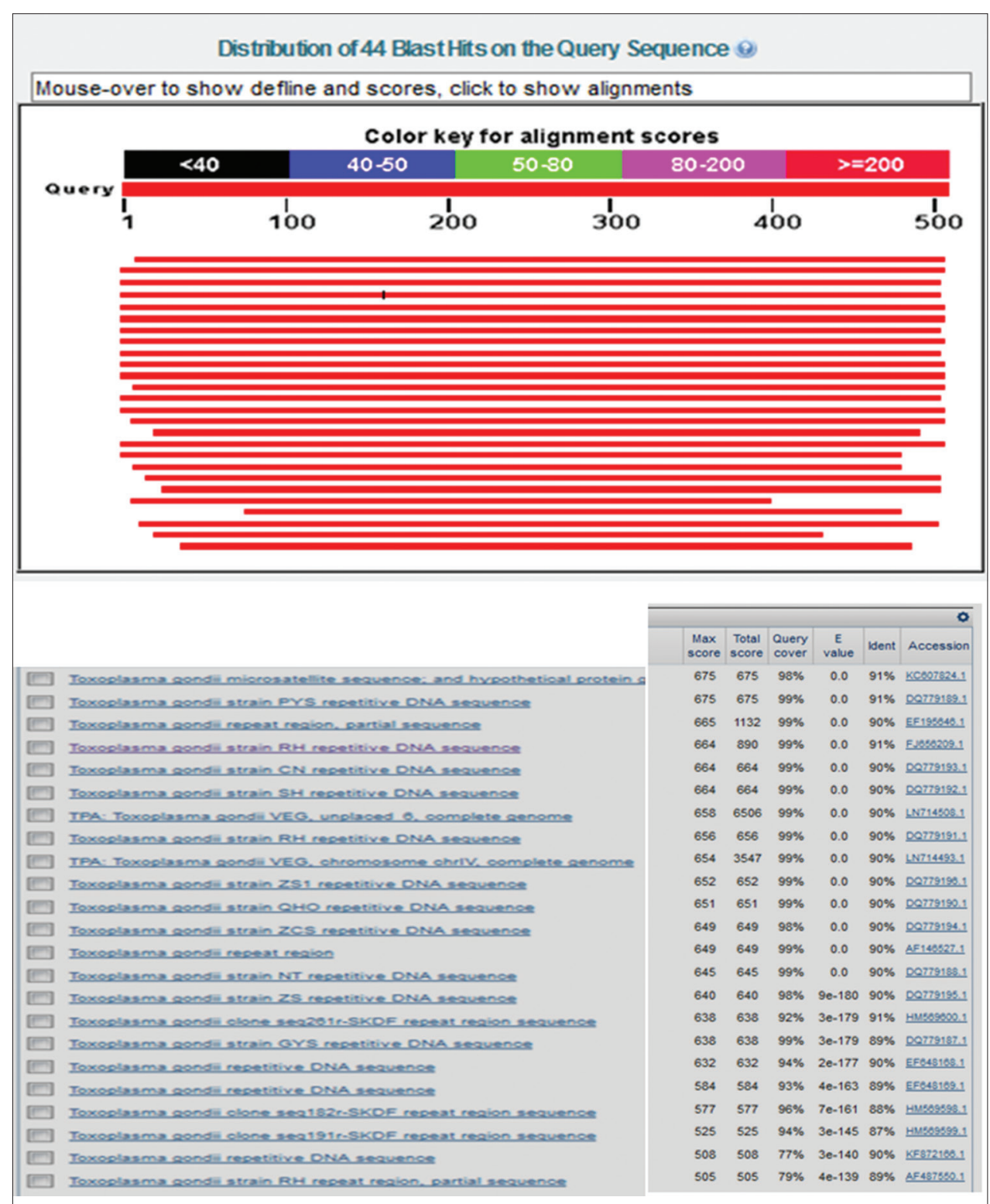

Figure-3: The result of output BLASTN sequence repetitive R529 (sequencing product).

concentration of $12 \mathrm{ng} / \mathrm{ml}$. The detection limit of the conventional PCR varied depending on the amounts of pure $T$. gondii tachyzoites that were mixed with whole blood. A decreased performance of conventional PCR may be expected when exceeding a certain amount of non-specific DNA in a reaction volume.

Phylogenetic tree construction of Toxoplasma (Figure-4) grouped into two clades which clade 1 consists of $T$. gondii repeat region repetitive 529 from India isolate and clade 2 consists of Toxoplasma with some strains from GenBank that is $T$. gondii CN DQ779193.1 strain, T. gondii NT DQ779188.1 strain, T. gondii PYS DQ779189.1 strain, T. gondii QHO DQ779190.1 strain, T. gondii ZS1 DQ779196.1 strain, and $T$. gondii RH 531 strain (from China) and with some research samples such as toxo control, Yogya pet cat sample T1, T2, and T3 (from Yogyakarta/ Indonesia).

The source of infection of Toxoplasma in clade 1 was human Toxoplasma whereas clade 2 came from animal and human. This research similar to experiment conducted by Franco et al. [34] which indicated that Indonesian isolate (IS-1) classified into strain RH, however in this research it has been classified more detail in which IS-1 is grouped into China RH strain which slightly different from clade as India RH strain.

The formation of clade in this research is almost the same as research reported by Hartati [35] in approximately 40 chronic Toxoplasma infection animals, and 60 human toxoplasmosis cases showed a high correlation between biological phenotype and genetical characteristic of a certain parasite.

Based on the results, it can be assumed that the sample of toxoplasma used in this study was belonged to strain II that is RH strain and also from animal suffered from a chronic infection. Sibley and Howe [36] stated that there is a difference in replication rate between $T$. gondii Type I, II, and III. T. gondii Type I replication rate was higher than Type II and III. Even though statistically it showed not significantly 


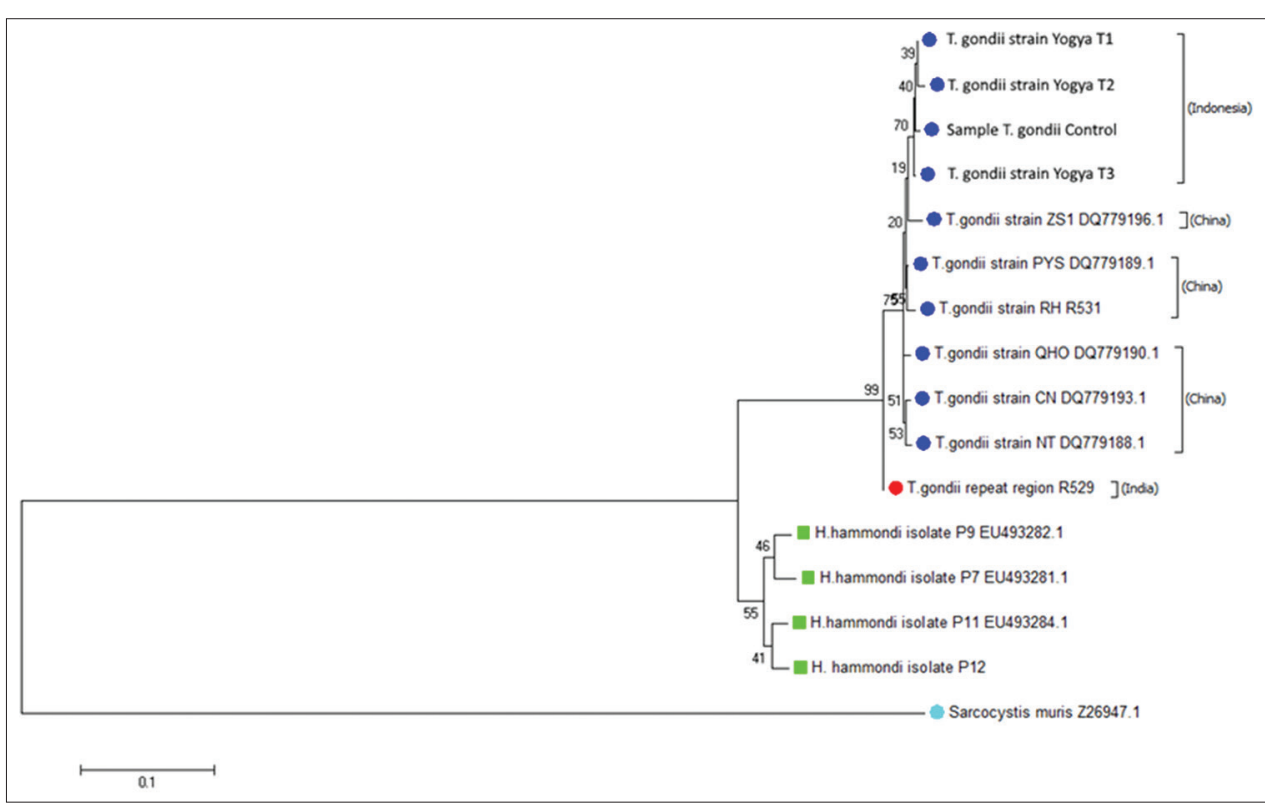

Figure-4: Phylogenetic tree analysis based on repetitive 529 DNA partial sequence that used for confirmative identification of Toxoplasma gondii isolates by neighbor-joining method.

different, the cumulative effect on the amount of cell and tissue destruction showed very significantly different, specifically in the rate of lytic process.

The phylogenetic study had placed the repetitive sequences of RH strain in different clades although the sequence was shared higher homologies among other RH strain from different places [37]. Homology analysis showed that the strain has $90-91 \%$ sequence similarity. This is slightly lower than those reported by Christina et al. [38], Parmley et al. [39], and Costa and Bretagnea [40] which was $92.8 \%$.

\section{Conclusion}

1. Copro-prevalence of toxoplasmosis in pet cats in Yogyakarta by means of PCR, using repetitive 529 bp gene sequences are around 33.33\%.

2. The phylogenetic tree of Toxoplasma grouped into two clades, which clade 1 consists of Toxoplasma isolates collected from pet cats in Yogyakarta Indonesia and T.gondii isolates from China and in clade 2 consist of the $T$. gondii isolates from India.

\section{Authors' Contributions}

MH dan RWN supervised the overall research work. JP, SH, and DA participated in sampling, made available relevant literature and executed the experiment and analyzed the Toxoplasma oocysts and DNA sequencing results. All authors interpreted the data, critically revised the manuscript for important intellectual contents and approved the content.

\section{Acknowledgments}

The authors would like to thank Mrs. Arsiah from PAU UGM, Yogyakarta, in DNA extraction and sending the DNA sequencing and also Mr. Harto from the Parasitology Department, FKH UGM, Yogyakarta, in helping the identification of Toxoplasma oocysts and documentation the results. This study was supported by the Ministry of Research, Technology, and Higher Education of the Republic of Indonesia (No. 019/ UN11.2/LT/SP3/2015).

\section{Competing Interests} interests.

The authors declare that they have no competing

\section{References}

1. Hill, D.E. and Dubey, J.P. (2013) Toxoplasma gondii prevalence in farm animals in the United States. Int. J. Parasitol., 43(2): 107-113.

2. Elmore, S.A., Jones, J.L., Conrad, P.A., Patton, S., Lindsay, D.S. and Dubey, J.P. (2010) Toxoplasma gondii: Epidemiology, feline aspects, and prevention. Trends Parasitol., 26(4): 190-196.

3. Riaz, F., Rashid, M., Akbar, H., Shehzad, W., Islam, S., Arshad, B., Saeed, K. and Ashraf, K (2016) DNA amplification techniques for the detection of Toxoplasma gondii tissue cysts in meat producing animals: A narrative review article. Iran. J. Parasitol.,11(4): 431-440.

4. Jones, J.L., Moran, K.D., Rivera, H.N., Price, C. and Wilkins, P.P. (2014) Toxoplasma gondii seroprevalence in the United States 2009-2010 and comparison with the past two decades. Am. J. Trop. Med. Hyg., 90(6): 1135-1139.

5. Loss, S.R., Will, T. and Marra, P.P. (2013) The impact of free-ranging domestic cats on wildlife of the United States. Nat. Comm, 4:1396.

6. Hanafiah, M., Nurcahyo, R.W., Yuniar, R.S., Prastowo, J., Hartati, S., Sutrisno, B. and Aliza, D. (2017) Detection of Toxoplasma gondii in cat's internal organs by immunohistochemistry methods labeled with-[strept] avidin-biotin. Vet. World, 10(9): 1035-1039.

7. Dehkordi, F.S., Haghighi, B.M.R., Rahimi, E. and Abdizadeh, R. (2013) Detection of Toxoplasma gondii in raw caprine, ovine, buffalo, bovine, and camel milk using cell cultivation, cat bioassay, capture ELISA, and PCR methods in Iran. Foodborne Pathog. Dis., 10(2): 120-125.

8. Contini, C., Seraceni, S., Cultrera, R., Incorvaia, C., Sebastiani, A. and Picot, S. (2005) Evaluation of a real-time PCR-based assay using the lightcycler system for detection of Toxoplasma gondii bradyzoite genes in blood specimens from patients with toxoplasmic retinochoroiditis. Int. J. Parasitol., 35(3): 275-283. 
9. Caldearo, A., Piccolo, G., Gorrini, C., Peruzzi, S., Zerbini, L., Bommezzadri, S., Dettori, G. and Chezzi, C. (2006) Comparison between two real-time PCR assays and a nested-PCR for the detection of Toxoplasma gondii. Acta Bio.Med., 77(2): 75-80.

10. Bastien, P., Jumas-Bilak, E., Varlet-Marie, E. and Marty, P. (2007) Three years of multi-laboratory external quality control for the molecular detection of Toxoplasma gondii in amniotic fluid in France. Clin. Microbiol. Infect., 13(4): 430-433.

11. Liu, Q., Wang, Z.D., Huang, S.Y. and Zhu, X. Q. (2015) Diagnosis of toxoplasmosis and typing of Toxoplasma gondii. Parasit.Vector, 8: 292.

12. Salant, H., Spira, D. and Hamburger J.A. (2010) A comparative analysis of coprologic diagnostic methods for detection of Toxoplasma gondii in cats. Am. J. Trop. Med. Hyg., 82(5): 865-870.

13. Stojanovic, V. and Foley P. (2011) Infectious disease prevalence in a feral cat population on Prince Edward Island. Canada, Can. Vet. J., 52(9): 979-982.

14. Jones, C.D., Okhravi, N., Adamson, P., Tasker, S. and Lightman, S. (2000) Comparison of PCR detection methods for B1, P30 and 18S rDNA genes of Toxoplasma gondii in aqueous humor. Invest. Ophthalmol. Vis. Sci., 41(3): 634-644.

15. Garcia, J.L., Jennari, S.M., Navarro, I.T., Machado, R.Z., Sinhorini, I.L. and Freire, R.L. (2005) Partial protection against tissue cyst formation in pigs vaccinated with crude rhoptry protein of Toxoplasma gondii. Vet. Parasitol., 129(3-4): 209-217.

16. Singh, B. (1997) Molecular methods for diagnosis and epidemiological studies of parasitic infections. Int. J. Parasitol., 27(10): 1135-1145.

17. Orlandi, P.A. and Lampel, K.A. (2000) Extraction- free, filter-based template preparation for rapid and sensitive PCR detection of pathogenic parasitic protozoa. J. Clin. Microbiol., 38(6): 2271-2277.

18. Abbasi, I., Branzburg, A., Campos-Ponce, M., Abdel Hafez, S.K., Raoul, F., Craig, P.S. and Hamburger, J. (2003) Coprodiagnosis of Echinococcus granulosis infection of dogs by amplification of a newly identified repeated DNA sequence. Am. J. Trop. Med. Hyg., 69(3): 324-330.

19. Soulsby, E.J.L. (1982) Helminths, Anthropods and Protozoa of Domesticated Animals. $7^{\text {th }}$ ed. The English Language of Book Society and Bailliere Tindal, London. p507-645.

20. Homan, W.L, Vercammen, M., De Braekeleer, J., Verschueren, H. (2000) Identification of a 200- to $300-$ fold repetitive $529 \mathrm{bp}$ DNA fragment in Toxoplasma gondii, and its use for diagnostic and quantitative PCR. Int. J. Parasitol., 30(1):69-75.

21. Simamora,A.T.A.J., Suratman, N.A. and Apsari, I.A.P. 2015. Isolation and Identification of Toxoplasma gondii oocysts in cat feces in Denpasar with sugar flotation method Sheater. Indo. Med. Vet., 4(2): 88-96.

22. Liang, Y., Chen, J.Q., Meng, Y., Zou, F.C., Hu, J.J. and Esch, G.W. (2016) Occurrence and genetic characterization of GRA6 and SAG2 from Toxoplasma gondii oocysts in cat feces, Kunming, China. Southeast Asian J. Trop. Med. Public Health., 47(6): 1134-1142.

23. Dubey, J.P., Darrington, C., Tiao, N. (2013) Isolation of viable Toxoplasma gondii from tissues and feces of cats from Addis Ababa, Ethiopia. J. Parasitol., 99(1): 56-58.

24. Haddadzadeh, H.R., Khazraiinia, P., Aslani, M., Rezaeian, M., Jamshidi, S., Taheri, M. and Bahonar, A. (2006). Seroprevalence of Toxoplasma gondii infection in stray and household cats in Tehran. Vet. Parasitol., 138(3-4): 211-216.
25. Akhtardanesh, B., Ziaali, N., Sharifi, H. and Hezaei, S.H. (2010) Feline immunodeficiency virus, feline leukemia virus and Toxoplasma gondii in stray and household cats in Kerman-Iran: Seroprevalence and correlation with clinical and laboratory findings. Res. Vet. Sci., 31: 306-310.

26. Dubey, J.P. (1986) Toxoplasmosis in cats. Feline. Pract., 16(4): $12-26$

27. Virgen, J., Castillo, M., Karla, Y., Acosta, V., Eugenia De, S., Guzm'an, M., Matilde Jim'enez, C., Jos'e, C. Segura-Correa, C., Aguilar-Caballero, A.J. and Antonio, P.O. (2012) Prevalence and risk factors of Toxoplasma gondii infection in domestic cats from the tropics of Mexico using serological and molecular tests. Int. Perspect. Infect. Dis., 20: 1-6.

28. Bolais, P.V., Vignoles, P., Pereira, P.F., Keim, R., Arousi, A., Ismail, K., Dardé, M.L., Amendoira, M. R. and Mercier, A. (2017) Toxoplasma gondii survey in cats from two environments of the city of Rio de Janeiro, Brazil by modified agglutination test on sera and filter-paper. Parasit. Vectors, 10(1): 88

29. Emily, L.L. and Caroline, D.W. (2013) High prevalence of Toxoplasma gondii oocyst shedding in stray and pet cats (Felis catus) in Virginia, United States. Parasit. Vectors, 6: 266.

30. Feitosa, T.F., Vilela, V.L.R., Dantas, E.S., Souto, D,V.O., Pena, H.F.J., Athayde, A.C.R. and Azevêdo, S.S. (2014) Toxoplasma gondii and Neospora caninum in domestic cats from the Brazilian semi-arid: Seroprevalence and risk factors. Arq. Bras. Med. Vet. Zootec., 66(4): 1060-1066.

31. Bizhga, B. (2017) Toxoplasmosis under coproscopic diagnosis in cats. Albanian. J. Agric. Sci., 10: 597-603.

32. Gashout, A., Amro, A., Erhuma, M., Al-Dwibe, H., Elmaihub, E., Babba, H., Nattah, N. and Abudher, A. (2016) Toxoplasma gondii in Libya. BMC. Infect. Dis., 16: $157-163$

33. Nascimentoa, C.O.M., Silvab, M.L.C.R., Kima, P.C.P., Gomesb, A.A.B., Gomesc, A.L.V., Maiac, R.C.C., Almeidad, J.C. and Motaa, R.A. (2015) Occurrence of Neospora caninum and Toxoplasma gondii DNA in brain tissue from hoary foxes (Pseudalopex vetulus) in Brazil. Acta Trop., 146: 60-65.

34. Franco, C.W.A., de Araújo, F.A.P. and Gennari, S.M. (2013) Toxoplasma gondii in small neotropical wild felids. Braz. J. Vet. Res. Anim. Sci., 50: 50-67.

35. Hartati, S. (2007) The Characterization of SAG1 and R522 Gene, and the Production of SAG1 as Toxoplasma gondii Isolate Local IS-1 Recombinant in Developing Toxoplasmosis Diagnose. Dissertation, Gadjah Mada University, London.

36. Sibley, L.D. and Howe, D.K. (1996) Genetic basis of pathogenicity in toxoplasmosis. In: Gross, U., editor. Toxoplasma gondii. Springer-Verlag, Berlin. p3-15.

37. Ralte, L S., Baidya, J.A., Pandit, S., Jas. R., Nandi, A., Taraphder, S., Isore, D.P., Jana, C. and Ranjan, R. (2017) Detection of Toxoplasma gondii targeting the repetitive microsatellite sequence by PCR. Explor. Anim. Med. Res., 7(2): $159-164$

38. Christina, N., Oury, B., Ambroise, T.P. and Santoro, F. (1991) Restriction fragment length polymorphisms among Toxoplasma gondii strains. Parasitol. Res., 77: 266-268.

39. Parmley, S.F., Gross, U., Sucharczuk, A., Windeck, T., Sgarlato, G.D. and Remington, J.S. (1994) Two alleles of the gene encoding surface antigen p22 in 25 strains of Toxoplasma gondii. J. Parasitol., 80: 293-301.

40. Costa, J. and Bretagnea, S. (2012) Variation of B1 gene and AF146527 repeat element copy numbers according to Toxoplasma gondii strains assessed using real-time quantitative PCR. J. Clin. Microbiol., 50(4): 1452-1454. 